\title{
Isolation and characterization of novel lipases/esterases from a bovine rumen metagenome
}

\author{
Florence Privé • C Jamie Newbold • Naheed N. Kaderbhai • \\ Susan G. Girdwood • Olga V. Golyshina • Peter N. Golyshin • \\ Nigel D. Scollan • Sharon A. Huws
}

Received: 24 September 2014 / Revised: 4 December 2014 / Accepted: 22 December 2014 /Published online: 11 January 2015

(C) The Author(s) 2015. This article is published with open access at Springerlink.com

\begin{abstract}
Improving the health beneficial fatty acid content of meat and milk is a major challenge requiring an increased understanding of rumen lipid metabolism. In this study, we isolated and characterized rumen bacterial lipases/esterases using functional metagenomics. Metagenomic libraries were constructed from DNA extracted from strained rumen fluid (SRF), solid-attached bacteria (SAB) and liquid-associated rumen bacteria (LAB), ligated into a fosmid vector and subsequently transformed into an Escherichia coli host. Fosmid libraries consisted of 7,744; 8,448; and 7,680 clones with an average insert size of 30 to $35 \mathrm{kbp}$ for SRF, SAB and LAB, respectively. Transformants were screened on spirit blue agar plates containing tributyrin for lipase/esterase activity. Five $\mathrm{SAB}$ and four LAB clones exhibited lipolytic activity, and no positive clones were found in the SRF library. Fosmids from positive clones were pyrosequenced and twelve putative lipase/esterase genes and two phospholipase genes retrieved. Although the derived proteins clustered into diverse esterase and lipase families, a degree of novelty was seen, with homology ranging from 40 to $78 \%$ following BlastP searches. Isolated lipases/esterases exhibited activity against mostly short- to medium-chain substrates across a range of temperatures and $\mathrm{pH}$. The function of these novel enzymes recovered
\end{abstract}

Electronic supplementary material The online version of this article (doi:10.1007/s00253-014-6355-6) contains supplementary material, which is available to authorized users.

F. Privé · C. J. Newbold • N. N. Kaderbhai · S. G. Girdwood •

N. D. Scollan $\cdot$ S. A. Huws $(\square)$

Institute of Biological, Environmental and Rural Sciences,

Aberystwyth University, Aberystwyth SY23 3DA, UK

e-mail: hnh@aber.ac.uk

O. V. Golyshina • P. N. Golyshin

School of Biological Sciences, Bangor University,

Bangor LL57 2UW, UK in ruminal metabolism needs further investigation, alongside their potential industrial uses.

Keywords Rumen $\cdot$ Lipolysis $\cdot$ Fatty acid $\cdot$ Lipase $\cdot$ Esterase $\cdot$ Bacteria $\cdot$ Functional metagenomic

\section{Introduction}

Rumen lipid metabolism plays a significant role in regulating the overall lipid composition of microbial cells and also of meat and milk produced by ruminants (Harfoot and Hazlewood 1997; Scollan et al. 2006; Lourenço et al. 2010; Shingfield et al. 2013). The lipid content of forage ingested by ruminants ranges from 2 to $10 \%$ of the total dry weight (Harfoot and Hazlewood 1997), which represent $1.5 \mathrm{~kg}$ of ingested lipids through forage per day by dairy cattle (Harfoot 1978). Dietary lipids enter the rumen either as triglycerides (neutral lipids) in concentrate-based feeds or as glycolipids or phospholipids (polar lipids) in forages (Harfoot and Hazlewood 1997; Bauman et al. 2003). Other polar lipids, like sulpholipids, are also present as minor components in forage $(<5 \%)$ (Harfoot and Hazlewood 1997). Fresh forage is typically composed of approx. $50 \% 18: 3$ n-3, $15 \% 18: 2$ n-6 and $15 \% 16: 0$ with the rest being minor contributions from other fatty acids (Huws et al. 2009; Huws et al. 2012).

Nonetheless, the fatty acid content of meat and milk does not directly correspond to that in their diets, with ruminant products being relatively high in saturated fatty acids. This is due to lipolysis and subsequent biohydrogenation of dietary lipids within the rumen. On entering the rumen, lipids are hydrolyzed by lipases/esterases, which results in the liberation 
of glycerol and unsaturated and saturated fatty acids. These fatty acids go through microbial biohydrogenation and are transformed to more saturated end products. Indeed, approximately $92 \% 18: 3$ n-3 and $86 \% 18: 2$ n-6 ingested are biohydrogenated in the rumen (Lourenço et al. 2010; Huws et al. 2010; Huws et al. 2011; Shingfield et al. 2013; Huws et al. 2014).

Research on lipid metabolism in the rumen has largely focused on biohydrogenation of polyunsaturated fatty acids; however, there is a dearth of data on microbial lipolysis, the first step in lipid metabolism in the rumen. Lipolysis is a crucial step in rumen lipid metabolism, and its control could subsequently alter the degree of ruminal biohydrogenation. It is known that dietary lipids are predominantly hydrolyzed in the rumen by obligate anaerobic bacteria (Jenkins et al. 2008), and there is little convincing evidence that rumen protozoa and/or fungi are significantly involved in ruminal lipolysis (Harfoot and Hazlewood 1997; Lourenço et al. 2010, Jenkins et al. 2008). However, to date, only six pure cultures of obligately anaerobic, lipolytic bacteria have been isolated from the rumen, including Anaerovibrio lipolytica isolated in the 1960s (Hobson and Mann 1961; Henderson 1970; Henderson 1971; Prins et al. 1975; Privé et al. 2013) and other bacteria belonging to the genera Butyrivibrio, Clostridium and Propionibacterium (Jarvis and Moore 2010). Nonetheless, the major hurdle of being able to culture many of the rumen bacteria means that we are potentially missing a wealth of information on rumen bacterial lipolysis.

Since the first published paper detailing functional metagenomic-based techniques for enhanced gene discovery in whole populations, irrespective of the ability to culture (Handelsman 1994), there has been an explosion in its use resulting in the discovery of many novel enzymes. Indeed, many new families of lipases/esterases have been discovered as a result of developments in functional metagenomic technologies (Nagarajan 2012). Nonetheless, functional metagenomic studies have only retrieved a small number of lipolytic enzymes, including two lipases from the rumen of cattle (Liu et al. 2009) and two esterases from the rumen of sheep (Bayer et al. 2010). In both cases, the isolated genes had only low similarities with lipases from other environments and their significance in rumen function is unknown.

Clearly, in order to be able to manipulate rumen lipid metabolism through control of lipolysis, we must first gain a better fundamental understanding of lipolysis. As such, the aims of this study were to increase our library of discovered lipases/esterases from the rumen metagenome and to gain a better understanding of ruminal lipases/esterases, their biochemical characteristics and the microbes that possess them.

\section{Materials and methods}

\section{Rumen sampling and DNA extraction}

Rumen contents were collected from four rumen-fistulated, non-lactating Holstein cows (average weight of $731 \mathrm{~kg}$ ) housed at Trawsgoed experimental farm (Aberystwyth, Ceredigion, Wales). Samples were retrieved under the authorities of the UK Animal (Scientific Procedures) Act (1986). The animals were fed a diet composed of a mixture of grass silage and straw (75:25) ad libitum, and $\sim 1 \mathrm{~kg}$ of sugar beet nuts was fed at $0700 \mathrm{~h}$ daily with constant access to fresh water. Sampling was completed $2 \mathrm{~h}$ after concentrate feeding. Strained ruminal fluid (SRF), solid-attached bacteria (SAB) and liquid-associated bacteria (LAB) were harvested as described previously by Huws et al. (2010). Essentially, $2 \mathrm{~h}$ after the morning feed, whole rumen fluid $(1 \mathrm{~L})$ was taken from each steer. Rumen samples were squeezed through a sieve, with some SRF kept, before the separation of rumen solids from the retained solids. SAB were obtained by washing of rumen solids $(500 \mathrm{~g})$ in saline $(2 \mathrm{~L})$, to detach all loosely attached microorganisms, and subsequently hand squeezing before stomaching solids in saline for $5 \mathrm{~min}$ to remove the attached microorganisms. The liquid fraction was then centrifuged $(800 \mathrm{~g}, 15 \mathrm{~min})$ to remove eukaryotes, before the supernatant was centrifuged twice $(13,000 \mathrm{~g}, 25 \mathrm{~min})$ and resuspended in saline. LAB were obtained by performing the low-speed and high-speed centrifugal steps as described on the liquid fraction obtained after initial hand squeezing of the retrieved rumen sample.

\section{Construction of metagenomic libraries}

Metagenomic DNA was extracted from $200 \mu \mathrm{L}$ of SRF, SAB and LAB using the BIO101 FastDNA ${ }^{\circledR}$ Spin Kit for Soil (Qbiogene, Cambridge, UK) following the supplier's protocol but with $3 \times 30$-s bead beating with 1 -min intervals on ice. The libraries were constructed using the CopyControl ${ }^{\mathrm{TM}}$ pCC1FOS ${ }^{\mathrm{TM}}$ vector and the reagents supplied in the CopyControl ${ }^{\mathrm{TM}}$ Fosmid Library Production Kit (Epicentre, Cambio Ltd., Cambridge, UK), following the supplier's recommendations. All clones were picked using a colony picker Genetix QPix2 XT (Genetix Ltd., New Milton, England) and subcultured for $20 \mathrm{~h}$ in 384-well plates (Genetix Ltd., New Milton, England) containing Luria Bertani broth (LB) with $12.5 \mu \mathrm{g} / \mathrm{mL}$ chloramphenicol and $20 \%$ glycerol. They were then stored at $-80^{\circ} \mathrm{C}$.

Screening for lipase activity

Selective screening of the clones for lipolytic activity was accomplished using spirit blue agar (Sigma-Aldrich Ltd., Dorset, UK) supplemented with $1 \%$ tributyrin. The media 
were supplemented with $12.5 \mu \mathrm{g} / \mathrm{mL}$ chloramphenicol for selection and $2 \mathrm{~mL} / \mathrm{L}$ of CopyControl Fosmid Autoinduction Solution (Epicentre, Cambio Ltd., Cambridge, UK) for highcopy-number induction of the clones. The medium was poured into square plates $(22 \times 22 \mathrm{~cm})$, and the clones were stamped onto the agar using a 384-pin replicator (Genetix Ltd., New Milton, England). After incubation for $48 \mathrm{~h}$ at $37^{\circ} \mathrm{C}$, clones surrounded by a blue precipitate on spirit blue agar were selected. Positive clones were retested for lipase activity with a secondary screening, and their fosmids were extracted using the QIAprep ${ }^{\circledR}$ Spin Miniprep kit (Qiagen, Crawley, UK) following the supplier's recommendations. The fosmid size was determined after restriction cutting with Bam HI and analysis on an agarose gel.

Discovery of lipase/esterase genes within putatively positive fosmids

Putatively lipase/esterase positive fosmids were sequenced using a high-throughput pyrosequencing GS FLX instrument (454 Life Sciences) at Aberystwyth University, UK. The purified lipase-positive fosmids were fragmented to 600-900-bp fragments by nebulization, undertaken according to Roche recommendations. The sheared fosmids were ligated to molecular barcodes (Multiplex Identifiers (MID), Roche Life Sciences; Table S1) containing short oligonucleotide adaptors "A" and "B". This was in order to specifically tag each sample in the sequencing run. A standard flowgram format (SFF) file was obtained for each sample, and nucleotide sequence data and phred-like quality scores were extracted. The reads from each of the pooled libraries were identified by their MID tags by the data analysis software gsAssembler v2.5.3 (Roche Life Sciences) after the sequencing run. The assembly was done using the default parameters on gsAssembler. BlastN on NCBI was used to trim the vector sequence from the contigs. The GC content was calculated with BioEdit. The open reading frames (ORFs) were characterized using ORF Finder (available at [http://www.ncbi.nlm.nih.gov/gorf/gorf.html]), BlastN (non-redundant nucleotide collection) and BLASTP (non-redundant protein sequences database) on NCBI.

The theoretical molecular mass and isoelectric point of the deduced amino acid sequences were calculated using the Compute $\mathrm{pI} / \mathrm{MW}$ tool on the ExPASy proteomics server (available at http://expasy.org/tools/pi tool.html). Signal sequences for peptide cleavage were analyzed using SignalP 4.0 (Petersen et al. 2011) using the Gram-negative model. Conserved domains in the amino acid sequences were analyzed with Conserved Domain Search on NCBI (MarchlerBauer et al. 2011) and the Pfam database (version 25.0, available at http://pfam.sanger.ac.uk/). Phylogenetic analysis was conducted by carrying out multiple sequence alignments using the ClustalW online tool (available at http://www.ebi. ac.uk/Tools/msa/clustalw2/) for the protein sequences using default settings. Closely related homologs were identified from the NCBI non-redundant database using BLASTP searches. Sequences with alignment $>50 \%$ identities and evalue $<1 \mathrm{e}^{-10}$ were considered. As the classification of lipolytic enzymes is based on the comparison of their protein sequences (Arpigny and Jaeger 1999; Hausmann and Jaeger 2010), the protein sequences from 50 members representing eight lipolytic families were retrieved from NCBI (Liu et al. 2009). A multiple sequence alignment file was constructed using ClustalW online tool on the Pfam conserved domains ( $\alpha / \beta$ hydrolase fold or esterase/lipase domain). MEGA5 software (Tamura et al. 2011) was used to construct the tree using the neighbour-joining method by following Dayhoff PAM matrix model.

Expression and purification of recombinant lipases

Primers for the amplification of the lipase genes were designed with FastPCR 6.1 (Kalendar et al. 2009), with and without the N-terminal signal sequence where one could be identified (Table S2). The PCR reaction was set up in a total volume of $25 \mu \mathrm{L}$ as follows: $2 \mu \mathrm{L}$ of template $(\sim 100 \mathrm{ng}), 1 \mu \mathrm{L}$ of forward and reverse primers $(10 \mathrm{pM}), 8.5 \mu \mathrm{L}$ of molecular water and $12.5 \mu \mathrm{L}$ of PCR mastermix (ImmoMix ${ }^{\mathrm{TM}}$, Bioline UK Ltd., London, UK). Initial activation of the Taq was performed for $10 \mathrm{~min}$ at $95{ }^{\circ} \mathrm{C}$, followed by 25 cycles as follows: $95^{\circ} \mathrm{C}$ for $30 \mathrm{~s}, 50^{\circ} \mathrm{C}$ for $30 \mathrm{~s}$ and $72^{\circ}$ for $2 \mathrm{~min}$, followed by a final extension at $72{ }^{\circ} \mathrm{C}$ for $8 \mathrm{~min}$ and holding of samples at $4{ }^{\circ} \mathrm{C}$. After PCR, the products were verified by electrophoresis on a $1 \%$ agarose gel using a $1-\mathrm{kb}$ ladder. The band of interest was cut out with a sterile razor blade and the DNA eluted using the MinElute Gel Extraction kit (Qiagen, Crawley, UK).

The expression of the lipolytic genes was then undertaken using the pTrcHis $\mathrm{TOPO}^{\circledR}$ TA Expression kit (Invitrogen, Carlsbad, CA, USA) following the supplier's protocol. The PCR product was ligated to the pTrcHis TOPO vector and transformed into Escherichia coli TOP10 cells. Twelve colonies for each transformation were picked for secondary screening, and their insert was analyzed for size and orientation by tip-dip PCR using the gene-specific forward primer and the vector-specific pTrcHis reverse primer (5'-GATTTA ATCTGTATCAGG-3'). Proteins were purified from $50 \mathrm{~mL}$ cultures in the presence of $50 \mu \mathrm{g} / \mathrm{mL}$ ampicillin. A starter culture $(2 \mathrm{~mL})$ grown in LB containing $50 \mu \mathrm{g} / \mathrm{mL}$ ampicillin (inoculated with a single colony) was incubated overnight at $37^{\circ} \mathrm{C}$ with shaking. The starter culture was used to inoculate $50 \mathrm{~mL}$ of LB (2\% inoculation) followed by incubation at $37{ }^{\circ} \mathrm{C}$ with shaking for $2 \mathrm{~h}$. Following the 2-h incubation (mid-log growth phase), the culture was induced with $1 \mathrm{mM}$ isopropyl $\beta$-D-1-thiogalactopyranoside (IPTG) and incubated at $37^{\circ} \mathrm{C}$ with shaking for $5 \mathrm{~h}$ to express the enzyme (this was previously validated to be the optimum conditions for maximal protein expression). The cells were then harvested by 
centrifugation at $3000 \times \mathrm{g}$, for $10 \mathrm{~min}$, at $4{ }^{\circ} \mathrm{C}$, and the pellets stored at $-80{ }^{\circ} \mathrm{C}$ before proceeding to protein purification. Purification of the proteins from the whole pellet was carried out in native conditions using the ProBond ${ }^{\mathrm{TM}}$ Purification System (Invitrogen, Carlsbad, CA, USA) following the supplier's protocol. Protein was eluted with $8 \mathrm{~mL}$ native elution buffer ( $\mathrm{pH}$ 8.0) $(50 \mathrm{mM}$ monobasic sodium phosphate $(\mathrm{pH}$ 8.0 ), $0.5 \mathrm{M} \mathrm{NaCl}, 0.25 \mathrm{M}$ imidazole ( $\mathrm{pH} 6.0)$ ). The purity of the proteins was examined by sodium dodecyl sulphate polyacrylamide gel electrophoresis (SDS-PAGE). SDS-PAGE was performed using a $15 \%$ separating and a $4.5 \%$ stacking gel. Protein concentrations were estimated using the Bradford procedure (Bradford, 1976) employing BSA as the standard (Sigma, Dorset, UK).

\section{Enzymatic assays}

Enzyme activity was quantified on a temperature-controlled PowerWave XS microplate reader (BioTek Instruments Inc., Potton, UK) based on the concentration of $\rho$-nitrophenol released following the hydrolysis of $\rho$-nitrophenyl ester substrates by the enzyme. The production of $\rho$-nitrophenol was monitored in triplicate every minute for $10 \mathrm{~min}$ at $410 \mathrm{~nm}$, and data were collected with the software Gen5 v1.10 (BioTek Instruments Inc., Potton, UK). Unless otherwise described, enzyme activity was measured by a standard assay at $39{ }^{\circ} \mathrm{C}$, with $1 \mathrm{mM} \rho$-nitrophenyl ester substrates $(\mathrm{C} 4-\mathrm{C} 18)$ in $50 \mathrm{mM}$ morpholineethanesulphonic acid (MES, pH 6.5) containing $1 \%$ acetonitrile. After preincubation for $3 \mathrm{~min}$, the reaction was started by the addition of $2 \mu \mathrm{L}$ of the eluted fraction of purified enzyme $(\sim 0.4 \mathrm{mg} / \mathrm{mL})$. Blank reactions were performed with every measurement to subtract appropriate values for nonenzymatic hydrolysis of the substrate. One unit of enzyme activity was defined as the amount of activity required to release $1 \mu \mathrm{mol}$ of $\rho$-nitrophenol/min from $\rho$-nitrophenyl ester. The enzymes' substrate specificity was also tested by titrating the release of free fatty acids from triglycerides as described by Pinsirodom and Parkin (2001). Tributyrin (C4), tricaprylin (C8) and triolein (C18:1) were used. An emulsion containing $500 \mu \mathrm{L}$ of substrate in $5 \mathrm{~mL}$ of MES (pH 6.5) containing $0.5 \mathrm{mg}$ of gum arabic was preincubated for $15 \mathrm{~min}$ at $39^{\circ} \mathrm{C}$ with stirring. The enzyme $(140 \mu \mathrm{L}$, $\sim 50 \mathrm{mg}$ ) was added to initiate lipolysis, and the time was set to T0. At 2.5-, 5-, 10- and 15-min reactions, $600 \mu \mathrm{L}$ of the reaction mixture was sampled and transferred to a tube containing $1.2 \mathrm{~mL}$ of $95 \%(v / v)$ ethanol to stop the reaction. The contents of the tube were then titrated with $0.005 \mathrm{M} \mathrm{NaOH}$ until the $\mathrm{pH}$ reached 10.0. The blank was set as a tube containing $1.2 \mathrm{~mL}$ of $95 \%(v / v)$ ethanol and $500 \mu \mathrm{L}$ of substrate. One unit of lipase activity was defined as the amount of activity required to produce $1 \mu \mathrm{mol}$ of fatty acid per minute.
Effect of $\mathrm{pH}$ on enzyme activity

The effect of $\mathrm{pH}$ on the enzymes was examined across the $\mathrm{pH}$ range 3.5 to 10.0 using a wide-range $\mathrm{pH}$ buffer containing $40 \mathrm{mM}$ each of acetic acid, MES, $N$-(2-hydroxyethyl) piperazine- $N^{\prime}$ - ethanesulphonic acid (HEPES), $N$-[Tris(hydroxymethyl) methyl]-3-aminopropanesulphonic sodium salt (TAPS) and $N$-cyclohexyl-3-aminopropane sulphonic acid (CAPS). The $\mathrm{pH}$ was adjusted by adding $1 \mathrm{M}$ $\mathrm{HCl}$ or $1 \mathrm{M} \mathrm{NaOH}$ as appropriate at $39{ }^{\circ} \mathrm{C}$. The specific activity of the enzyme was determined spectrophotometrically at $348 \mathrm{~nm}$ as it is the $\mathrm{pH}$-independent isobestic wavelength of $\rho$-nitrophenoxide and $\rho$-nitrophenol (Hotta et al. 2002).

Effect of temperature on enzyme stability and thermostability/refolding efficiency

The effect of temperature on the enzyme activity was examined across the range $25-70{ }^{\circ} \mathrm{C}$ under standard assay conditions. The $\mathrm{pH}$ of the MES buffer was adjusted to 6.5 at respective temperatures. The thermostability of the enzymes was analyzed by measuring the residual activity after incubating the enzyme $(2 \mu \mathrm{L}$ in $50 \mathrm{mM}$ MES, $\mathrm{pH}$ 6.5) for $1 \mathrm{~h}$ at 50,60 and $70{ }^{\circ} \mathrm{C}$.

\section{Effect of metal ions on enzyme activity}

The effect of metal ions on the activity of the enzymes was investigated by incubating the enzymes with various metal chloride salts $\left(\mathrm{Na}^{+}, \mathrm{K}^{+}, \mathrm{NH}_{4}^{+}, \mathrm{Mg}^{2+}, \mathrm{Ca}^{2+}, \mathrm{Mn}^{2+}, \mathrm{Zn}^{2+}\right.$, $\mathrm{Co}^{2+}$ ) at final concentrations of $5 \mathrm{mM}$ in $50 \mathrm{mM}$ MES (pH 6.5) for $30 \mathrm{~min}$ at room temperature. The remaining activity was then measured under standard assay conditions.

Sequence accession numbers

The nucleotide sequences of the genes reported here are available in the GenBank database under accession numbers JX469447 to JX469462. The full fosmid sequences are also available in the GenBank database under the BioSample ID: SAMN03144433.

\section{Results}

Screening for lipase activity from metagenomic libraries

The metagenomic libraries consisted of a total of 23,872 clones: 7,744 from SRF, 8,448 from SAB and 7,680 from $\mathrm{LAB}$, with a range of insert sizes of $30-35 \mathrm{kbp}$. The libraries were screened using a spirit blue assay. Five clones from the $\mathrm{SAB}$ library and four clones from the LAB library were 
positive for lipolytic/esterase activity (Fig. S1). There were no positive clones observed from the SRF library. The putatively positive SAB fosmids: SAB5A16, SAB16A18, SAB16E6, SAB18J4 and SAB28M4, contained 31, 19, 31, 16 and $20 \mathrm{kbp}$ of metagenomic material, respectively, whilst the LAB fosmids: LAB4P4, LAB8M16, LAB9D24 and LAB9P23, contained of 28, 39, 33 and $18 \mathrm{kbp}$ metagenomic DNA, respectively.

The protein coding sequences in fosmids SAB5A16, SAB16A18, SAB16E6, SAB18J4, SAB28M4, LAB4P4, LAB8M16 and LAB9P23 were more closely related to Prevotella ruminicola 23 and Bacteroides species; nonetheless, the matches were often low, and possibly, the matches to these bacteria were due to the fact that they have been genome sequenced and, therefore, dominate the GenBank database (Tables S3, S4, S5, S6, S7, S8, S9 and S11). Coding sequences in fosmid LAB9D24 were most closely related to Butyrivibrio fibrisolvens, Ruminococcus sp., Bacteroides sp. and Prevotella sp. (Table S10). Fourteen putative genes showing similarity to known esterase/lipase genes were retrieved and were named lip1 to lip14, and two patatin-like phospholipase genes were also found and named pll and pl2 (Table 1). No lipase genes were retrieved from LAB8M16 or LAB9D24, either because of the incomplete assembly of the fosmid sequence due to low sequence coverage or possibly because the blue hue observed between 20 and $24 \mathrm{~h}$ in the spirit blue agar plate assay was a false positive.

Table 1 Putative lipase/esterase genes and features of the encoded proteins identified using a tributyrin spirit blue screen of the rumen metagenome of cattle

\begin{tabular}{llllll}
\hline Fosmid & Gene & $\begin{array}{l}\text { Length } \\
\text { (bp) }\end{array}$ & $\begin{array}{l}\text { Protein } \\
\text { size (aa) }\end{array}$ & $\begin{array}{l}\text { Protein } \\
\text { molecular } \\
\text { weight }(\mathrm{kDa})\end{array}$ & $\begin{array}{l}\text { Theoretical } \\
\text { isoelectric } \\
\text { point }\end{array}$ \\
\hline SAB5A16 & lip1 & 1578 & 525 & 58.86 & 4.82 \\
& lip2 & 1584 & 527 & 58.88 & 4.89 \\
& lip3 & 1749 & 582 & 65.67 & 4.63 \\
SAB16A18 & lip4 & 1743 & 580 & 65.46 & 4.53 \\
& lip5 & 1581 & 526 & 58.71 & 4.93 \\
& lip6 & 1563 & 520 & 58.28 & 4.95 \\
SAB16E6 & lip7 & 1059 & 352 & 38.93 & 5.66 \\
& lip8 & 930 & 309 & 31.79 & 5.71 \\
& p11 & 1239 & 412 & 47.38 & 8.67 \\
SAB18J4 & lip9 & 1560 & 519 & 58.26 & 5.15 \\
& lip10 & 1677 & 558 & 62.58 & 5.32 \\
SAB28M4 & lip11 & 963 & 320 & 35.48 & 6.41 \\
& lip12 & 1086 & 361 & 40.07 & 6.34 \\
& pl2 & 2301 & 766 & 85.67 & 8.77 \\
LAB4P4 & lip13 & 846 & 281 & 31.67 & 6.26 \\
LAB9P23 & lip14 & 1059 & 352 & 38.55 & 5.14 \\
\hline
\end{tabular}

Classification of lipases

BlastN analysis showed that the gene sequences of lip1, lip2, lip3, lip4, lip5, lip6, lip9 and lip10 had 74 to $80 \%$ sequence identity to the gene 023 coding for an ester hydrolase in an uncultured marine prokaryote (AJ811969). Genes lip7, lip12 and lip14 possessed 70-72\% sequence identity to an esterase gene isolated from an uncultured bacterium from a cow rumen metagenome, whilst lip8 and lip11 possessed $75 \%$ sequence identity to an esterase/lipase gene retrieved from a phagemid clone from a bovine rumen metagenomic library (Table S12). Phospholipase genes pl1 and pl2 did not show any similarity to sequences documented in GenBank using BlastN. The deduced amino acid sequences of the genes were used to perform a BLASTP search against the NCBI database. Lip3, lip4, lip7, lip8, lip11, lip12 and lip14 possessed between 50 and $78 \%$ identity to other esterases/lipases from uncultured rumen bacteria (ADE28720, ABI17943, CAJ19128). A higher similarity (63 to $84 \%$ identity) was also observed between lip1, lip2, lip5, lip6, lip9 and lip10 and the ester hydrolase from an uncultured marine prokaryote (CAH19079). Lip13 possessed $78 \%$ similarity to a lipase from P. ruminicola 23 . Phospholipases pl1 and pl2 were 40 and $51 \%$ identity, respectively, related to the patatin family phospholipase of Prevotella oralis ATCC33269 (Table S13). Nonetheless, despite some similarity to known lipases/esterases, the \% homologies confirm that the enzymes discovered within this study have a degree of novelty.

Phylogenetic placement of the predicted proteins suggests lipases from all the main lipase families described by Arpigny and Jaeger (1999) (Fig. 1). Domain analysis confirmed that lip1, lip2, lip5, lip6, lip9 and lip10 contained domains linked to lipase and esterase activity (esterase/lipase superfamily domain, carboxylesterase domain). Lip8 and lip11 contained an $\alpha / \beta$ hydrolase fold domain, whilst lip3, lip4, lip7, lip12 and lip14 had a DUF3089 domain, which represents an $\alpha / \beta$ hydrolase fold and, therefore, putative enzymatic activity. Lip13 contained a rhamnogalacturonan esterase-like domain. P11 and $\mathrm{p} 12$ were predicted to be outer membrane proteins, and p12 also contained a patatin-like phospholipase domain and a domain predicted to code for an esterase of the $\alpha / \beta$ hydrolase family. Proteins lip3, lip4, lip7, lip10, lip12, lip13, lip14 and pl 2 were predicted to be secreted enzymes based on the presence of a putative signal peptide.

Lip8 and lip11 clustered with genes from family IV as defined by Arpigny and Jaeger (1999) (Fig. 1). This was confirmed by multiple alignments with proteins from this family (Fig. S2), and lip8 and lip11 contained the lipase-conserved catalytic triad of residues Glu, replacing Asp (residue 229 and 263 for lip 8 and lip11, respectively), His (259 and 293, respectively) and the catalytic nucleophile Ser $(138,172)$, respectively, in the consensus pentapeptide GDSAG. The HSL family conserved HGGG motif, amino acids 69 to 71 and 103 


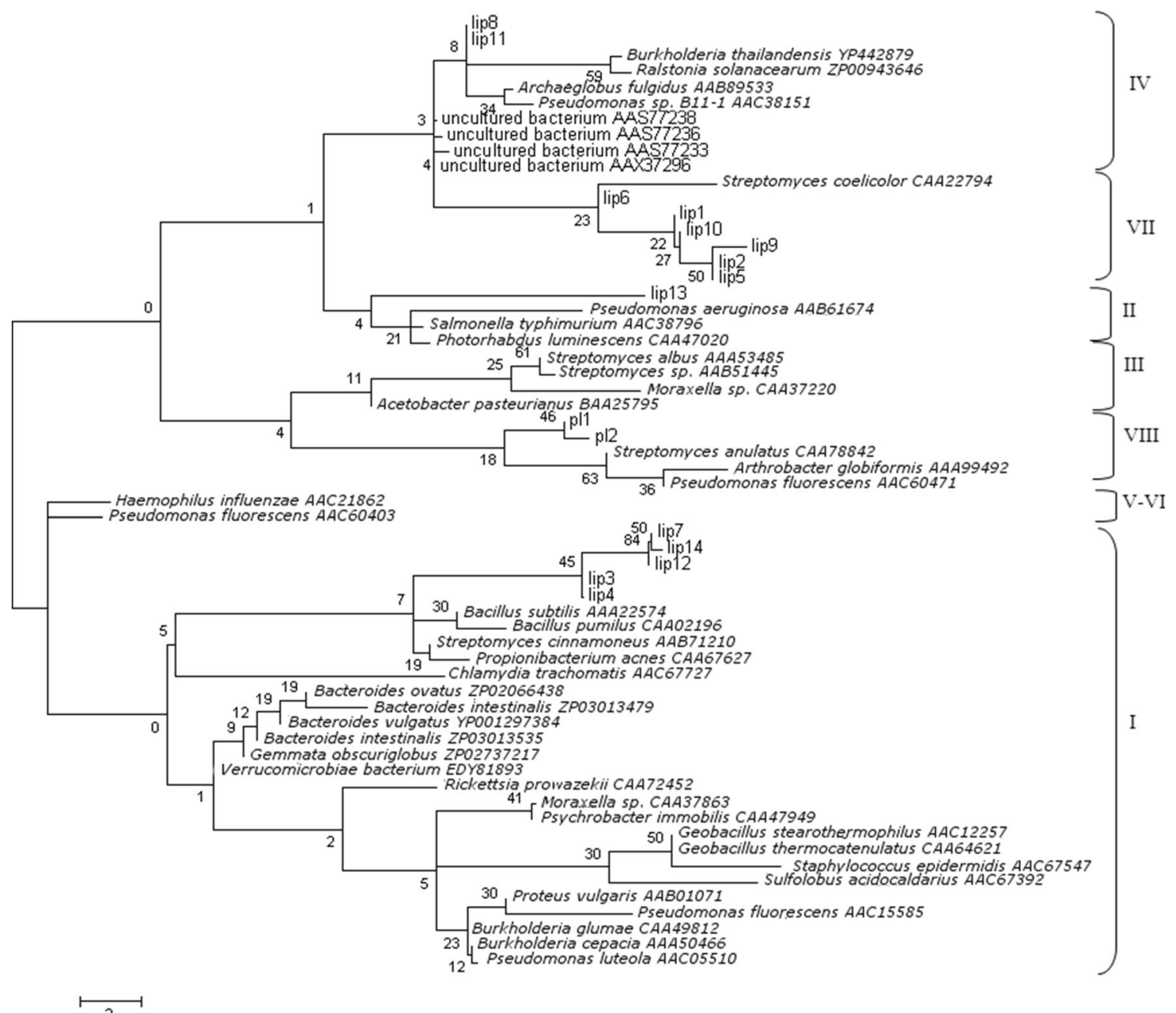

Fig. 1 Neighbour-joining analysis of lip1 to lip14 and lipolytic proteins from different families. The scale indicates the number of substitution events. The numbers associated with the branches refer to the bootstrap

to 105 , respectively, was found upstream of the active-site conserved motif. Alignments indicated that lip1, lip2, lip5, lip6, lip9 and lip10 might be more closely related to family VII. Multiple amino acid alignment (Fig. S3) with enzymes related to this family provided confirmation: the catalytic triad was present with Asp, His and Ser in the consensus motif GESAG. Lip13 clustered with the so-called GDSL enzymes from family II. The active site motif GDS(L) was found in the $\mathrm{N}$-terminus of the protein sequence, and elements of the five blocks of conserved amino acids were present in its sequence (Fig. S4). The dendrogram (Fig. 1) suggested that lip3, lip4, lip7, lip12 and lip14 clustered with true lipases from subfamily I.7. Multiple amino acid alignments with lipases included in this family showed that the proteins contained the conserved motif GHSQG (Fig. S5). However, the alignments did not show other conserved blocks and the putative catalytic triad was not identified for lip3, lip4 and lip14 with the Asp missing. Pl1 and pl 2 clustered with enzymes from family VIII; however, multiple amino acid alignments did not show values (confidence limits) resulting from 1000 replicate resamplings. Roman numerals correspond to the lipolytic families as defined by Arpigny and Jaeger (1999)

conserved motifs characteristic from this enzyme family (data not shown).

Biochemical characterization of purified lipases/esterases

In order to investigate the biochemical properties of the enzymes, they were expressed using the pTrcHis TOPO vector in E. coli TOP10. Based on the level of expression obtained with each protein and in order to analyze proteins from each lipase family (Fig. 1), the proteins from fosmid libraries lip4, lip6, lip13ss, pl1 and p12ss were chosen for purification and further characterization. Proteins lip13ss and pl2ss were produced using primers that amplified the protein minus signal peptides as the cloning of active lipases with their signal peptides was unsuccessful. Purification, following induction with IPTG $(1 \mathrm{mM})$ for $5 \mathrm{~h}$ and after elution from the nickel resin routinely, yielded 0.2 to $0.4 \mathrm{mg} / \mathrm{mL}$ of purified protein from $50 \mathrm{~mL}$ cultures. 
In terms of substrate specificity, Lip4 and lip13ss showed narrow chain length specificity, with the highest specific activity against $\rho$-nitrophenyl laurate (373.4 and $398.6 \mathrm{U} / \mathrm{mg}$, respectively) and a lower specific activity against $\rho$ nitrophenyl caprate (107.7 and $214.6 \mathrm{U} / \mathrm{mg}$, respectively); activity against other substrates was very low or not detected (Table 2). Protein lip6 exhibited the typical behaviour for carboxylesterases, showing a preference for short acyl chains (Table 2). The highest specific activity was observed with $\rho$ nitrophenyl butyrate $(273.3 \mathrm{U} / \mathrm{mg})$, and activity values decreased with the increase in the acyl chain length (Table 2). Pl1 showed a broader range of activity with higher specific activities against short to medium acyl chain length: the activities were respectively $247.8 \mathrm{U} / \mathrm{mg}$ with $\rho$-nitrophenyl butyrate, $317.5 \mathrm{U} / \mathrm{mg}$ with $\rho$-nitrophenyl caprylate and $224.6 \mathrm{U} /$ mg with $\rho$-nitrophenyl caprate and laurate. Pl2ss showed no identifiable substrate preference (Table 2). There was some release of free fatty acids from tributyrin, tricaprylin and triolein indicating some activity against the longer-chain triglycerides (Table 2).

In terms of $\mathrm{pH}$ tolerance, proteins Lip4, lip6, lip13ss and pl1 had maximal activity at neutral or slightly alkaline $\mathrm{pH}$ (7 or 7.5). Lip6, lip13ss and pl1 exhibited $>50 \%$ activity in the $\mathrm{pH}$ range of 6.5-8.0, while lip4 showed activity over a broader $\mathrm{pH}$ range as it presented $53 \%$ of its maximum activity level at $\mathrm{pH} 10 . \mathrm{P} 2 \mathrm{ss}$ had optimum $\mathrm{pH}$ at 8.5 , respectively, and presented activity $>50 \%$ in alkaline $\mathrm{pH}$ range $8.5-10.0$ (Fig. 2).

The optimum temperatures were determined as $40^{\circ} \mathrm{C}$ (lip4, lip6, lip13ss), $45{ }^{\circ} \mathrm{C}$ (pl1) and $30^{\circ} \mathrm{C}$ (pl2ss) (Table 3 and Fig. 3). The temperature range where the enzyme retained more than $50 \%$ activity was narrow for lip4 (around $40{ }^{\circ} \mathrm{C}$ ), pl1 $\left(45-50{ }^{\circ} \mathrm{C}\right)$ and lip13ss (around $40{ }^{\circ} \mathrm{C}$ ), while it was broader for lip6 $\left(40-50{ }^{\circ} \mathrm{C}\right)$ and pl2ss $\left(25-40{ }^{\circ} \mathrm{C}\right)$ (Table 3 and Fig. 3). The proteins lip4, lip13ss, and pl1 appeared to be temperature sensitive as less than $50 \%$ of activity was measured after 1-h incubation at $50{ }^{\circ} \mathrm{C}$ (Table 3 and Fig. 3). Lip6 appeared to have some thermostability: at $50{ }^{\circ} \mathrm{C}$, it had $57.9 \%$ activity but lost activity after incubation at 60 or $70{ }^{\circ} \mathrm{C}$ (Table 3 and Fig. 3). Protein pl2ss displayed some thermostability as it displayed nearly $90 \%$ of its activity after incubation at 50 and $60^{\circ} \mathrm{C}$ and lost only $30 \%$ of its activity after incubation at $70{ }^{\circ} \mathrm{C}$ (Table 3 and Fig. 3).

In terms of the effects of ion addition, lip4 activity was strongly inhibited by $\mathrm{NH}_{4}^{+}, \mathrm{Mg}^{2+}, \mathrm{Ca}^{2+}, \mathrm{Zn}^{2+}$ and $\mathrm{Co}^{2+}$ and moderately inhibited by $\mathrm{Na}^{+}$and $\mathrm{K}^{+}$, but no effect of $\mathrm{Mn}^{2+}$ was observed (Table 4). Lip6 activity was totally inhibited by $\mathrm{Mn}^{2+}$ and $\mathrm{Co}^{2+}$ and strongly inhibited by $\mathrm{K}^{+}, \mathrm{NH}_{4}{ }^{+}$and $\mathrm{Mg}^{2+}$ but only moderately inhibited by $\mathrm{Ca}^{2+}$ and $\mathrm{Zn}^{2+}$ while $\mathrm{Na}^{+}$ slightly increased its activity (Table 4). Only $\mathrm{Zn}^{2+}$ had a strong inhibitory effect on pll activity while $\mathrm{Na}^{+}, \mathrm{K}^{+}, \mathrm{NH}^{+}, \mathrm{Mg}^{2+}$ and $\mathrm{Co}^{2+}$ had moderate inhibitory effects and $\mathrm{Ca}^{2+}$ and $\mathrm{Mn}^{2+}$ had a stimulatory effect (Table 4). Lip13ss activity was strongly inhibited by $\mathrm{K}^{+}, \mathrm{Mg}^{2+}, \mathrm{Ca}^{2+}, \mathrm{Zn}^{2+}$ and $\mathrm{Co}^{2+}$ and more moderately by $\mathrm{Na}^{+}, \mathrm{NH}_{4}^{+}$and $\mathrm{Mn}^{2+}$ (Table 4$)$. Pl2ss was totally inhibited by $\mathrm{Ca}^{2+}$ and strongly inhibited by $\mathrm{Co}^{2+}$ $(57 \%)$, but its activity increased significantly with other ions (Table 4).

\section{Discussion}

In this study, we have isolated 14 novel lipase/esterase/phospholipase encoding genes from a bovine rumen microbiome.

Table 2 Substrate specificity of lipases/esterases isolated from the rumen metagenome of cattle

\begin{tabular}{|c|c|c|c|c|c|}
\hline \multirow[t]{2}{*}{ Substrate } & \multicolumn{5}{|c|}{ Specific activity (U/mg protein) } \\
\hline & lip4 & lip6 & lip13ss & pl1 & pl2ss \\
\hline \multicolumn{6}{|l|}{ pNP-acyl esters } \\
\hline Butyrate (C4) & $56.3 \pm 12.1$ & $273.3 \pm 22.5$ & ND & $247.8 \pm 11.1$ & $172.5 \pm 12.0$ \\
\hline Caproate (C6) & $28.7 \pm 24.9$ & $198.6 \pm 10.8$ & $51.1 \pm 14.5$ & $154.9 \pm 21.8$ & $58.8 \pm 20.4$ \\
\hline Caprylate (C8) & $36.0 \pm 23.7$ & $42.4 \pm 16.7$ & $20.5 \pm 14.4$ & $317.5 \pm 31.6$ & $141.2 \pm 17.0$ \\
\hline Caprate (C10) & $107.7 \pm 37.3$ & $30.5 \pm 5.1$ & $214.6 \pm 14.5$ & $224.6 \pm 5.5$ & $109.8 \pm 4.5$ \\
\hline Laurate (C12) & $373.4 \pm 45.7$ & $23.8 \pm 8.7$ & $398.6 \pm 7.1$ & $224.6 \pm 11.0$ & $274.5 \pm 36.3$ \\
\hline Myristate (C14) & $71.7 \pm 12.4$ & $18.7 \pm 4.3$ & $153.3 \pm 25.6$ & $209.1 \pm 20.4$ & $227.4 \pm 27.2$ \\
\hline Palmitate (C16) & ND & $13.6 \pm 7.0$ & ND & $162.6 \pm 32.4$ & $235.3 \pm 67.9$ \\
\hline Stearate $(\mathrm{C} 18)$ & ND & ND & ND & $46.5 \pm 32.8$ & $109.8 \pm 29.7$ \\
\hline \multicolumn{6}{|l|}{ Triglycerides } \\
\hline Tributyrin (C4) & 55.8 & 51.6 & 26.5 & 130.0 & 65.8 \\
\hline Tricaprylin (C8) & 55.8 & 56.8 & 26.5 & 65.0 & 131.7 \\
\hline Triolein $(\mathrm{C} 18: 1)$ & 55.8 & ND & ND & ND & 131.7 \\
\hline
\end{tabular}

$N D$ not detected 
Fig. 2 The effect of $\mathrm{pH}$ on the activity of lipases isolated from the rumen metagenome of cattle. The $\mathrm{pH}$ assays were carried out using $\rho$-nitrophenyl caprate (C10) as the substrate for lip4 and lip13ss, $\rho$-nitrophenyl caproate (C6) for lip6 and $\rho$-nitrophenyl caprylate (C8) for pl1 and pl2ss, at a constant temperature of $39^{\circ} \mathrm{C}$ in a wide-range $\mathrm{pH}$ buffer set at the indicated $\mathrm{pH}$ values
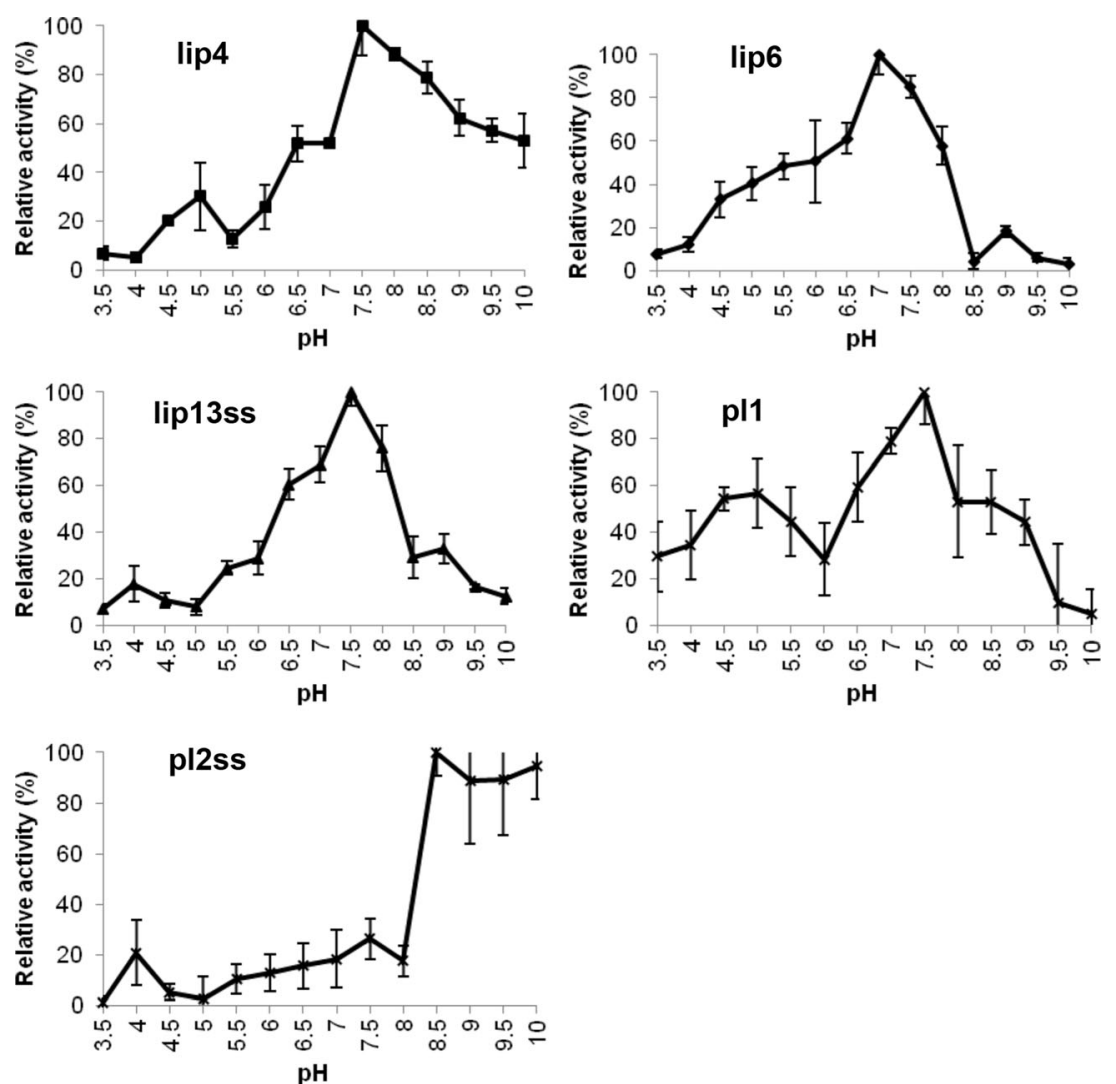

This is, to our knowledge, one of the most comprehensive of studies in terms of lipase/esterase gene retrieval from the rumen microbiota. This study illustrates that the rumen is a rich resource of novel enzymes, many of which remain undiscovered, and each of which could be useful for industrial applications, as well as serving to increase our fundamental understanding of rumen lipid metabolism.

The genes and the deduced proteins retrieved had varied degrees of similarity to genes previously found in typical ruminal bacteria such as Bacteroides and Prevotella species (27 to $99 \%$ amino acid similarity). Prevotella is one of the most predominant bacterial genera found in the rumen, accounting for up to $20 \%$ of the total bacteria found in sheep (Bekele et al. 2010), between 14 and $60 \%$ in dairy cows (Kong et al. 2010; Stevenson and Weimer, 2007) and up to $90 \%$ in steers (Huws et al. 2010; 2013). The publication of the P. ruminicola 23 and Prevotella bryantii $\mathrm{B}(1) 4$ genomes (Purushe et al. 2010) may explain why most of the fosmid sequences were similar to these entries as only limited information on other rumen bacteria is currently deposited.

The putative esterases and lipases identified were diversely distributed within the eight different lipolytic families defined by Arpigny and Jaeger (1999). They did not cluster in the same families as the two lipases Rlip1 and Rlip2 retrieved

Table 3 Relative activity of lipases/esterases isolated from a rumen metagenome of cattle after incubation for $1 \mathrm{~h}$ at 50,60 or $70{ }^{\circ} \mathrm{C}$

\begin{tabular}{llllll}
\hline Temperature of incubation $\left({ }^{\circ} \mathrm{C}\right)$ & \multicolumn{3}{l}{ Relative activity $(\%)$} & & \\
\cline { 2 - 6 } & lip4 & lip6 & lip13ss & pl1 & p12ss \\
\hline 40 & 100 & 100.0 & 100.0 & 100.0 & 100.0 \\
50 & $41.8 \pm 5.6$ & $57.9 \pm 4.3$ & $25.7 \pm 11.5$ & $37.0 \pm 10.5$ & $87.8 \pm 10.3$ \\
60 & $47.5 \pm 8.1$ & $11.5 \pm 7.8$ & $10.5 \pm 18.7$ & $15.1 \pm 7.0$ & $89.6 \pm 13.2$ \\
70 & $31.3 \pm 15.5$ & $13.0 \pm 4.3$ & $11.4 \pm 3.4$ & $16.5 \pm 7.0$ & $73.8 \pm 10.9$ \\
\hline
\end{tabular}

The enzymes were incubated for $1 \mathrm{~h}$ at 50,60 and $70{ }^{\circ} \mathrm{C}$ in $50 \mathrm{mM}$ MES buffer (pH 6.5); the residual activities were measured with a standard assay against $\rho$-nitrophenyl caprate (C10) for lip4 and lip13ss, $\rho$-nitrophenyl caproate (C6) for lip6 and $\rho$-nitrophenyl caprylate (C8) for pl1 and pl2ss. The activity of the enzyme at $40{ }^{\circ} \mathrm{C}$ was defined as $100 \%$ 
Fig. 3 The effect of temperature on the activity of lipases isolated from the rumen metagenome of cattle. The temperature assays were carried out using $\rho$ nitrophenyl caprate $(\mathrm{C} 10)$ as the substrate for lip4 and lip13ss, $\rho$ nitrophenyl caproate (C6) for lip6 and $\rho$-nitrophenyl caprylate $(\mathrm{C} 8)$ for pl1 and pl2ss, in a wide-range $\mathrm{pH}$ buffer with $\mathrm{pH}$ being 6.5 for all assays
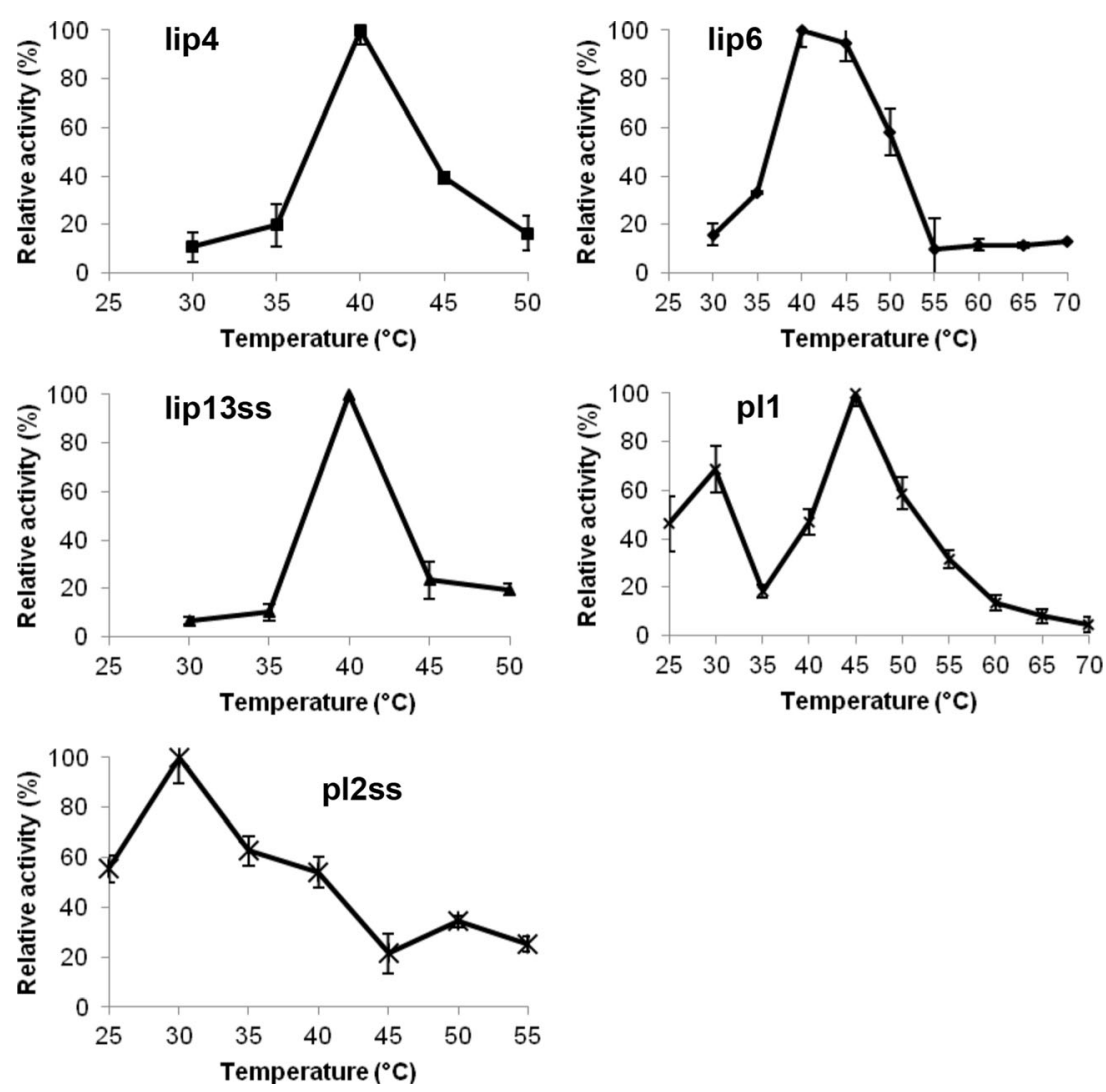

from a rumen metagenome library by Liu et al. (2009)). Multiple sequence alignments revealed the presence of highly conserved sequence blocks in the different families, particularly the Gly-Xaa-Ser-Xaa-Gly motif and the catalytic triad Ser, Glu/Asp and His. Lip3, lip4, lip7, lip12 and lip14 are proposed as new members of the lipase subfamily I.7. Little

Table 4 Effect of metal ions on the relative activity of lipases isolated from a bovine rumen metagenome

Relative activity (\%)

\begin{tabular}{llllll}
\hline Ions & lip4 & lip6 & lip13ss & pl1 & pl2ss \\
\hline $\mathrm{None}^{2}$ & 100.0 & 100.0 & 100.0 & 100.0 & 100.0 \\
$\mathrm{Na}^{+}$ & $69.8 \pm 1.8$ & $101.2 \pm 2.4$ & $75.9 \pm 1.5$ & $76.2 \pm 1.9$ & $119.2 \pm 23.0$ \\
$\mathrm{~K}^{+}$ & $88.4 \pm 1.8$ & $16.9 \pm 0.5$ & $49.8 \pm 2.0$ & $76.2 \pm 1.5$ & $260.2 \pm 30.7$ \\
$\mathrm{NH}_{4}^{+}$ & $51.2 \pm 1.6$ & $50.6 \pm 8.4$ & $61.7 \pm 1.1$ & $69.8 \pm 1.0$ & $151.8 \pm 21.4$ \\
$\mathrm{Mg}^{2+}$ & $55.8 \pm 9.4$ & $61.8 \pm 4.3$ & $26.1 \pm 1.7$ & $69.8 \pm 1.1$ & $137.3 \pm 8.7$ \\
$\mathrm{Ca}^{2+}$ & $25.6 \pm 1.2$ & $75.9 \pm 6.0$ & $45.1 \pm 6.0$ & $162.6 \pm 11.2$ & $0.0 \pm 6.9$ \\
$\mathrm{Mn}^{2+}$ & $100.0 \pm 6.0$ & $8.4 \pm 1.2$ & $90.1 \pm 1.1$ & $124.1 \pm 12.5$ & $115.6 \pm 12.5$ \\
$\mathrm{Zn}^{2+}$ & $39.5 \pm 1.7$ & $84.3 \pm 11.9$ & $7.1 \pm 2.5$ & $14.8 \pm 2.5$ & $368.6 \pm 14.5$ \\
$\mathrm{Co}^{2+}$ & $32.6 \pm 2.1$ & $0.0 \pm 10.7$ & $19.0 \pm 8.4$ & $70.9 \pm 1.3$ & $57.8 \pm 1.3$
\end{tabular}

The enzymes were incubated for $30 \mathrm{~min}$ in $50 \mathrm{mM}$ MES buffer ( $\mathrm{pH}$ 6.5) with the metal ions at $5-\mathrm{mM}$ final concentration; the residual activities were measured with a standard assay against $\rho$-nitrophenyl caprate (C10) for lip4 and lip13ss, $\rho$-nitrophenyl caproate (C6) for lip6 and $\rho$ nitrophenyl caprylate $(\mathrm{C} 8)$ for pl1 and pl2ss information is available on this family, as only three enzymes have been classified in this group, originating from Streptomyces cinnamoneus, Propionibacterium acnes and Corynebacterium glutamicum (Hausmann and Jaeger, 2010). Lip13 was classified in the esterase family II, or so-called GDSL enzymes, as the catalytic serine is retrieved in a GlyAsp-Ser-(Leu) tetrapeptide rather than the Gly-Xaa-Ser-XaaGly pentapeptide, and this important motif was found very close to the N-terminus, as noted for other GDSL enzymes (Arpigny and Jaeger 1999). As lip13 carried a rhamnogalacturonan esterase domain, rhamnogalacturonans being a group of plant cell wall pectic polysaccharides, it can be hypothesized that the secreted protein might be involved in plant cell wall degradation in the rumen (Kauppinen et al. 1995; Mølgaard et al. 2000). Lip8 and lip11 were included in family IV; three conserved sequence blocks are observed in these proteins. The HGGG motif, involved in the oxyanion hole stabilization, was found, as well as the possible catalytic triad residues. Lip1, lip2, lip5, lip6, lip9 and lip10 were classified, according to their sequence similarity, as members of family VII. Their molecular masses ranged from 58 to $62 \mathrm{kDa}$, which is close to the average molecular mass $(55 \mathrm{kDa})$ of esterases belonging to family VII (Hausmann and Jaeger 2010). The physiological role of these esterases is unclear; however, they have attracted interest for their use in many industrial processes (Hausmann and Jaeger 2010). The putative phospholipases pl1 and pl2 were 
both predicted to be outer membrane proteins (amino acid residues 9 to 241 and 357 to 766 , respectively). The amino acid sequence of $\mathrm{pl} 2$ also matched on the first part of the protein a predicted patatin-like phospholipase domain (amino acid residues 48 to 254) together with an esterase domain (amino acid residues 44 to 329). Patatin-like proteins have been proposed as a new family of lipolytic enzymes present in bacteria, since they do not share many similarities with other families apart from the Gly-Xaa-Ser-Xaa-Gly motif and were found to be related to eukaryotic phospholipases (Banerji and Flieger 2004). Patatin-like phospholipases have been mainly observed in pathogenic bacteria as virulence factors (Banerji and Flieger 2004).

Phospholipases are ubiquitous and diverse enzymes that mediate various cellular functions, such as membrane maintenance. Phospholipids also constitute most of the plant lipids ingested by herbivores. Phospholipases are classified into four major groups (A, B, C, D) based on their enzymatic specificity and the position at which they cleave within the phospholipid (Sitkiewicz et al. 2007). It is interesting to note that pl2ss activity was increased by $\sim 3.7$-fold in the presence of $\mathrm{Zn}^{2+}$, since several phospholipases $\mathrm{C}$ involved in pathogenic reactions are zinc metalloenzymes, like the $\alpha$-toxin from Clostridium perfringens (Tsutsui et al. 1995) and the phospholipase C from Listeria monocytogenes (Vazquez-Boland et al. 1992) and Bacillus cereus (Nakamura et al. 1988). However, pl2ss activity was inhibited in the presence of $\mathrm{Ca}^{2+}$, though this cation has often been associated with stimulation of activity due to the formation of calcium salts of long-chain fatty acids (Macrae and Hammond 1985). The lipase from Pseudomonas aeruginosa 10145 has likewise been observed to be inhibited, in the presence of calcium ions (Finkelstein et al. 1970). Helicobacter pylori, as well as other enteric bacteria, harbours phospholipases A on their outer membrane, and these enzymes participate in the modification of the composition of bacterial membranes, possibly to enhance bacterial growth, colonization and/or survival (Istivan and Coloe 2006). The characterization of these enzymes in the current study is not complete enough to determine their role in bacterial metabolism, and more work is required to assess pll and pl2ss role in their hosts. The specific activity observed for pl2ss after 1-h incubation at 50,60 or $70^{\circ} \mathrm{C}$ decreased by only 10 to $30 \%$, suggesting a possible use of pl2 in biotechnological applications. The half-life of the enzyme at higher temperatures should be assayed to further check this potential.

In summary, we have isolated 14 novel lipases/esterases from rumen bacteria. Lipases/esterases play a key role in regulating fatty acid metabolism in the rumen, and control of lipolysis in the rumen could play a vital role limiting biohydrogenation of polyunsaturated fatty acids. Lipases/ esterases are also very important enzymes for many biotechnological processes. Thus, further studies will concentrate on the role of these lipases/esterases in ruminal lipolysis as well as investigating their possible usefulness to the biotechnological industries.

Acknowledgments The authors are thankful for the technical assistance and guidance of Mrs. Hilary Worgan. The authors acknowledge funding from the Biotechnology and Biological Sciences Research Council (UK), Department of Environment Food and Rural Affairs, English Beef and Lamb Executive, Hybu Cig Cymru, Quality Meat Scotland and European Union ProSafeBeef (FOOD-CT-2006-36241).

Open Access This article is distributed under the terms of the Creative Commons Attribution License which permits any use, distribution, and reproduction in any medium, provided the original author(s) and the source are credited.

\section{References}

Arpigny JL, Jaeger K-E (1999) Bacterial lipolytic enzymes: classification and properties. Biochem J 343:177-183

Banerji S, Flieger A (2004) Patatin-like proteins: a new family of lipolytic enzymes present in bacteria? Microbiology 150:522-525

Bauman DE, Perfield JW, De Veth MJ, Lock AL (2003) New perspectives on lipid digestion and metabolism in ruminants. Proc Cornell Nutr Conf 175-189

Bayer S, Kunert A, Ballschmiter M, Greiner-Stoeffele T (2010) Indication for a new lipolytic enzyme family: isolation and characterization of two esterases from a metagenomic library. J Mol Microbiol Biotechnol 18:181-187

Bekele AZ, Koike S, Kobayashi Y (2010) Genetic diversity and diet specificity of ruminal Prevotella revealed by $16 \mathrm{~S}$ rRNA genebased analysis. FEMS Microbiol Lett 305:49-57

Finkelstein AE, Strawich ES, Sonnino S (1970) Characterization and partial purification of a lipase from Pseudomonas aeruginosa. Biochim Biophys Acta 206:380-391

Handelsman J (1994) Metagenomics: application of genomics to uncultured microorganisms. Microbiol Mol Biol Rev 68:669-685

Harfoot CG (1978) Lipid metabolism in the rumen. Progr Lipid Res 17: $21-54$

Harfoot CG, Hazlewood GP (1997) Lipid metabolism in the rumen. In: Hobson PN, Stewart CS (eds) The rumen microbial ecosystem. Blackie Academic and Professional Publishers, London, pp 382426

Hausmann S, Jaeger K-E (2010) Lipolytic enzymes from bacteria. In: Timmis KN (ed) Handbook of hydrocarbon and lipid microbiology. Springer, Berlin Heidelberg, pp 1099-1126

Henderson C (1970) The lipases produced by Anaerovibrio lipolytica in continuous culture. Biochem J 119(3):5P-6P

Henderson C (1971) A study of the lipase produced by Anaerovibrio lipolytica, a rumen bacterium. J Gen Microbiol 65:81-89

Hobson PN, Mann SO (1961) The isolation of glycerol fermenting and lipolytic bacteria from the rumen of the sheep. J Gen Microbiol 25: 227-240

Hotta Y, Ezaki S, Atomi A, Imanaka T (2002) Extremely stable and versatile carboxylesterase from a hyperthermophilic archaeon. Appl Environ Microbiol 68:3925-3931

Huws SA, Kim EJ, Lee MRF, Kingston-Smith AH, Wallace RJ, Scollan ND (2009) Rumen protozoa are rich in polyunsaturated fatty acids due to the ingestion of chloroplasts. FEMS Microbiol Ecol 69:461471 
Huws SA, Lee MRF, Muetzel SM, Scott MB, Wallace RJ, Scollan ND (2010) Forage type and fish oil cause shifts in rumen bacterial diversity. FEMS Microbiol Ecol 73(2):396-407

Huws SA, Kim EJ, Lee MRF, Pinloche E, Wallace RJ, Scollan ND (2011) As yet uncultured bacteria phylogenetically classified as Prevotella, Lachnospiraceae incertae sedis, and unclassified Bacteroidales, Clostridiales and Ruminococcaceae may play a predominant role in ruminal biohydrogenation. Env Micro 13:1500-1512

Huws SA, Lee MRF, Kingston-Smith AH, Kim EJ, Scott MB, Tweed J, Scollan ND (2012) Ruminal protozoal contribution to the flow of fatty acids following feeding of steers on forages differing in their chloroplast content. British J Nutr 1:1-8

Huws SA, Mayorga OL, Theodorou MK, Kim EJ, Newbold CJ, Kingston-Smith AH (2013) Successional colonisation of perennial ryegrass by rumen bacteria. Lett Appl Microbiol 56:186-196

Huws SA, Kim EJ, Cameron SJS, Girdwood SE, Davies L, Tweed J, Vallin H, Scollan ND (2014) Characterization of the rumen lipidome and microbiome of steers fed a diet supplemented with flax and echium oil. Microb Biotechnol. doi:10.1111/1751-7915.12164

Istivan TS, Coloe PJ (2006) Phospholipase A in Gram-negative bacteria and its role in pathogenesis. Microbiol 152:1263-1274

Jarvis GN, Moore ERB (2010) Lipid metabolism and the rumen microbial ecosystem. In: K. N. Timmis (ed) Handbook of hydrocarbon and lipid microbiology. Springer, Berlin Heidelberg, p 2246-2257.

Jenkins TC, Wallace RJ, Moate PJ, Mosley EE (2008) Recent advances in biohydrogenation of unsaturated fatty acids within the rumen microbial ecosystem. J Anim Sci 86:397-412

Kalendar R, Lee D, Schulman AH (2009) FastPCR software for PCR primer and probe design and repeat search. Genes, Genomes, Genomics 3:1-14

Kauppinen S, Christgau S, Kofod LV, Halkier T, Dörreich K, Dalbøge H (1995) Molecular cloning and characterization of a rhamnogalacturonan acetylesterase from Aspergillus aculeatus. J Biol Chem 270:27172-27178

Kong Y, Teather R, Forster R (2010) Composition, spatial distribution, and diversity of the bacterial communities in the rumen of cows fed different forages. FEMS Microbiol Ecol 74:612-62246

Liu K, Wang J, Bu D, Zhao S, McSweeney C, Yu P, Li D (2009) Isolation and biochemical characterization of two lipases from a metagenomic library of China Holstein cow rumen. Biochem Biophys Res Commun 385:605-611

Lourenço M, Ramos-Morales E, Wallace RJ (2010) The role of microbes in rumen lipolysis and biohydrogenation and their manipulation. Animal 4(7):1008-1023

Macrae AR, Hammond RC (1985) Present and future applications of lipases. Biotech Genet Eng Rev 3:193-217

Marchler-Bauer A, Lu S, Anderson JB, Chitsaz F, Derbyshire MK, DeWeese-Scott C, Fong JH, Geer LY, Geer RC, Gonzales NR, Gwadz M, Hurwitz DI, Jackson JD, Ke Z, Lanczycki CJ, Lu F, Marchler GH, Mullokandov M, Omelchenko MV, Robertson CL, Song JS, Thanki N, Yamashita RA, Zhang D, Zhang N, Zheng C,
Bryant SH (2011) CDD: a Conserved Domain Database for the functional annotation of proteins. Nucleic Acids Res 39:225-229

Mølgaard A, Kauppinen S, Larsen S (2000) Rhamnogalacturonan acetylesterase elucidates the structure and function of a new family of hydrolases. Structure 8(4):373-383

Nagarajan S (2012) New tools for exploring "old friends - microbial lipases". Appl Biochem Biotech 168:1163-1196

Nakamura S, Yamada A, Tsukagoshi N, Udaka S, Sasaki T, Makino S, Little C, Tomita M, Ikezawa H (1988) Nucleotide sequence and expression in Escherichia coli of the gene coding for sphingomyelinase of Bacillus cereus. FEBS J 175:213-220

Petersen TN, Brunak S, von Heijne G, Nielsen H (2011) SignalP 4.0: discriminating signal peptides from transmembrane regions. Nat Methods 8:785-786

Prins RA, Lankhorst A, Van der Meer P, Van Nevel CJ (1975) Some characteristics of Anaerovibrio lipolytica, a rumen lipolytic organism. Antonie Van Leeuwenhoek 41:1-11

Privé F, Huws SA, Kaderbhai NN, Golyshina OV, Scollan ND, Newbold CJ (2013) Identification and characterization of three novel lipases belonging to families II and V from Anaerovibrio lipolytica 5S. PLoS One 8:e69076

Purushe J, Fouts DE, Morrison M, White BA, Mackie RI.; North American Consortium for Rumen Bacteria, Coutinho PM, Henrissat B, Nelson KE (2010) Comparative genome analysis of Prevotella ruminicola and Prevotella bryantii: insights into their environmental niche. Microb Ecol 60:721-729

Scollan ND, Hocquette JF, Nuernberg K, Dannenberger D, Richardson I, Moloney A (2006) Innovations in beef production systems that enhance the nutritional and health value of beef lipids and their relationship with meat quality. Meat Sci 74(1):17-33

Shingfield KJ, Bonnet M, Scollan ND (2013) Recent developments in altering the fatty acid composition of ruminant-derived foods. Animal 7:132-162

Sitkiewicz I, Stockbauer KE, Musser JM (2007) Secreted phospholipase A2 enzymes: better living through phospholipolysis. Trends Microbiol 15:63-69

Stevenson DM, Weimer PJ (2007) Dominance of Prevotella and low abundance of classical ruminal bacterial species in the bovine rumen revealed by relative quantification real-time PCR. Appl Microbiol Biotechnol 75:165-174

Tamura K, Peterson D, Peterson N, Stecher G, Nei M, Kumar S (2011) MEGA5: Molecular Evolutionary Genetics Analysis using maximum likelihood, evolutionary distance, and maximum parsimony methods. Mol Biol Evol. doi:10.1093/molbev/msr121

Tsutsui K, Minami J, Matsushita O, Katayama S, Taniguch Y, Nakamura S, Nishioka M, Okabe A (1995) Phylogenetic analysis of phospholipase $\mathrm{C}$ genes from Clostridium perfringens types $\mathrm{A}$ to $\mathrm{E}$ and Clostridium novyi. J Bacteriol 177:7164-7170

Vazquez-Boland JA, Kocks C, Dramsi S, Ohayon H, Geoffroy C, Mengaud J, Cossart P (1992) Nucleotide sequence of the lecithinase operon of Listeria monocytogenes and possible role of lecithinase in cell-to-cell spread. Infect Immun 60:219-230 